\title{
Genetic variation in Staphylococcus aureus surface and immune evasion genes is lineage associated: implications for vaccine design and host-pathogen interactions
}

\author{
Alex J McCarthy* and Jodi A Lindsay
}

\begin{abstract}
Background: $\mathrm{S}$. aureus is a coloniser and pathogen of humans and mammals. Whole genome sequences of 58 strains of $S$. aureus in the public domain and data from multi-strain microarrays were compared to assess variation in the sequence of proteins known or putatively interacting with host.

Results: These included 24 surface proteins implicated in adhesion (ClfA, ClfB, Cna, Eap, Ebh, EbpS, FnBPA, FnBPB, IsaB, IsdA, IsdB, IsdH, SasB, SasC, SasD, SasF, SasG, SasH, SasK, SdrC, SdrD, SdrE, Spa and SraP) and 13 secreted proteins implicated in immune response evasion (Coa, Ecb, Efb, Emp, EsaC, EsXA, EssC, FLIPr, FLIPr like, Sbi, SCIN-B, SCIN-C, VWbp) located on the stable core genome. Many surface protein genes were missing or truncated, unlike immune evasion genes, and several distinct variants were identified. Domain variants were lineage specific. Unrelated lineages often possess the same sequence variant domains proving that horizontal transfer and recombination has contributed to their evolution. Surprisingly, sequenced strains from four animal S. aureus strains had surface and immune evasion proteins remarkably similar to those found in human strains, yet putative targets of these proteins vary substantially between different hosts. This suggests these proteins are not essential for virulence. However, the most variant protein domains were the putative functional regions and there is biological evidence that variants can be functional, arguing they do play a role.

Conclusion: Surface and immune evasion genes are candidates for $S$. aureus vaccines, and their distribution and functionality is key. Vaccines should contain cocktails of antigens representing all variants or they will not protect against naturally occurring $S$. aureus populations.
\end{abstract}

\section{Background}

Staphylococcus aureus is a highly adaptive and versatile gram-positive bacterium that has major importance to human and animal health. In humans $20 \%$ of a healthy population are persistently colonised in the anterior nares of the nose and a further $60 \%$ are intermittently colonised [1]. S. aureus is a common cause of minor skin and wound infections, but can cause serious and even fatal infections, particularly in the immunocompromised. The emergence of methicillin-resistant S. aureus (MRSA) worldwide is of major concern as this dramatically

* Correspondence: amccarth@sgul.ac.uk

${ }^{1}$ Centre for Infection, Department of Cellular and Molecular Medicine, St George's, University of London, Cranmer Terrace, London SW17 ORE, UK Full list of author information is available at the end of the article reduces the choice of effective antibiotics for prevention and treatment of a very common infection in both hospitals and communities [2].

S. aureus also colonises a range of mammals, including companion animals such as dogs, cats and horses, and livestock such as cows, pigs and goats. It can also colonise birds such as chickens and turkeys. All of these animal species can become infected with $S$. aureus, much like humans, and $S$. aureus is a common cause of dairy cow mastitis with substantial economic impact. Of further concern is the presence of MRSA strains in a variety of animals such as cats, dogs, horses, cows, pigs, chickens and rats [3-7]. These animals may act as important reservoirs for human colonisation as is the case for MRSA sequence type (ST)398 that colonises pigs. Understand- 
ing the roles of ecological, epidemiological and genetic factors, and specifically the host- pathogen molecular interactions, involved in host-to-host transmission and colonisation is essential for us to expose novel opportunities for the control of the pathogen. In particular, vaccines for preventing S. aureus infection in livestock and/or humans would be useful, but commercial livestock vaccines and human clinical trails have so far proved disappointing.

Adherence is an essential step required for bacterial colonisation of a new host. S. aureus can express a variety of surface bound proteins (also referred to as microbial surface components recognising adhesive matrix molecules, or MSCRAMMs) that interact with host extracellular ligands, such as collagen, fibrinogen (FG), fibronectin $(\mathrm{FN}-1)$, vitronectin $(\mathrm{VN})$, elastin $(\mathrm{ELN})$, prothrombin (PT) and von Willebrand factor (vWF) [8,9]. In addition, $S$. aureus produce a variety of secreted proteins involved in immune evasion or modulation, often targeting complement and neutrophil recruitment [10-12].

S. aureus populations consist of dominant lineages with some minor lineages. Multi- strain whole genome $S$. aureus microarray studies have shown that each $S$. aureus lineage is highly distinct, and that each lineage possesses a unique combination of conserved surface proteins and their regulators [13]. Difference also exists in the expression and secretion of S. aureus proteins [14]. The major human lineages are clonal complex (CC)1, CC5, CC8, CC9, CC12, CC15, CC22, CC25, CC30, CC45 and CC51 [15]. The lineages that have acquired $m e c A$ to become widespread hospital acquired (HA-)MRSA are CC5, CC8, CC22, CC30, CC45 and a hybrid lineage CC239 [16,17]. The lineages that have acquired $m e c A$ to become widespread community associated (CA-)MRSA are CC1, CC8, CC30, CC59 and CC80 [18]. Companion animals are usually colonised and infected with lineages typically seen in humans [4]. Cows are colonised and infected with their own different lineages that are rarely if ever found in humans, such as CC151, CC771, CC188, CC97, CC130 [14]. In contrast, pigs can be colonised (but are rarely infected) with CC398, which has acquired $m e c A$, and this lineage is capable of causing infection in humans $[18,19]$. Poultry are susceptible to infection with CC5 isolates [20]. Furthermore, there are known to be wide variations in the distribution of lineages between different geographical locations [21,22].

A bounty of new $S$. aureus genome sequences has recently been released into the public domain. Our overall aim was to investigate genetic variation in $S$. aureus core and lineage-specific surface and immune evasion proteins compared to their cognate host proteins, to better identify which are the most likely to be essential during colonisation and infection. We compared whole genome sequences of the first $58 \mathrm{~S}$. aureus genomes from
15 lineages and including 4 animal strains. We also extend our previous microarray analysis of human and animals isolates to include human MRSA lineages CC239, CC59 and CC80, and the pig MRSA clone CC398. Since our previous study, a number of new adhesion and immune evasion genes have been characterised, and these are also included in the analysis. Finally, we compared the known and putative human and animal protein targets that interact with $S$. aureus for genetic variation.

\section{Results}

Genes selected for sequence variation analysis fitted one of three criteria; genes that encode (i) surfaced bound proteins that possess LPxTG anchoring motifs (ii) proteins known to interact with host extracellular ligands (iii) secreted proteins that are known to have a role in immune evasion/modulation $[9,23]$. Gene sequences are avilable from a total of a total of $58 \mathrm{~S}$. aureus isolates (Table 1). 25 genes encoding surface bound proteins (Additonal file 1 Table S1) and 13 secreted proteins (Additonal file 2 Table S2) were analysed for sequence variation. Abbreviations of S. aureus and host genes and proteins are shown in tables 2 and 3.

\section{Sequence variation in surface bound $\mathrm{S}$. aureus proteins}

Eight (ebpS, fnbpA, isaB, isdA, isdH, sasF, sasH and spa) of the 25 genes that encode these surface bound proteins were present in all sequenced S. aureus genomes. Some of the remaining 16 genes were absent from a small number of $S$. aureus genomes (clfA, clfB, eap, ebh, fnbpB, isdB, sas $B$, sasC, sasD, sas $G, s d r C$, sdrD and $s r a P$ ) whilst others were absent from the majority of $S$. aureus genomes (cna, $s a s K$ and $s d r E$ ) (Additonal file 1 Table S1). This indicates that many surface bound proteins are not essential for survival and replication of $S$. aureus. Many of these proteins are known to adhere to the same host ligand and redundancy in S. aureus adhesins is common.

Variation was identified in all 25 surface bound proteins indicating that surface adhesins are not only present/ absent, but also variable amongst $S$. aureus genomes. Variation between lineages was higher than within lineages for all genes (Additonal file 1 Table S1). The protein domains at the host-interface had a higher level of interlineage variation in comparison to other protein domains for $12 \mathrm{~S}$. aureus surface bound proteins (Aaa, ClfA, ClfB, Eap, EbpS, FnBPA, FnBPB, SasG, SdrC, SdrD, SdrE and $\mathrm{Spa}$ ) (Additonal file 1 Table S1). The iron-regulated surface adhesins (IsdA, IsdB and IsdH), Cna, SasB and SraP have lower levels of interlineage variation present in putative host-interface domains than other protein domains. Knowledge of protein domains in the remaining 6 proteins is not currently available; nonetheless there are 
Table 1: Sequenced Staphylococcus aureus genomes

\begin{tabular}{|c|c|c|c|c|c|c|}
\hline \multicolumn{2}{|c|}{ Lineage } & \multirow[t]{2}{*}{ Strain } & \multirow[t]{2}{*}{ Host } & \multirow[t]{2}{*}{ Status } & \multirow[t]{2}{*}{ GenBank Accession number } & \multirow[t]{2}{*}{ Published reference } \\
\hline CC & ST & & & & & \\
\hline \multirow[t]{3}{*}{1} & 1 & MSSA476* & $\mathrm{H}$ & I & BX571857 & {$[48]$} \\
\hline & 1 & MW2* & $\mathrm{H}$ & I & BA000033 & [49] \\
\hline & 1 & $\mathrm{TCH} 70$ & $\mathrm{H}$ & $S$ & $\underline{\mathrm{NZ}} \mathrm{ACHH} 00000000$ & http://www.ncbi.nlm.nih.gov \\
\hline \multirow[t]{17}{*}{5} & 5 & A5937 & $\mathrm{H}$ & I & NZ ACKC00000000 & http://www.broadinstitute.org/ \\
\hline & 5 & A6224 & $\mathrm{H}$ & 1 & $\underline{\text { NZ ACKE } 00000000}$ & http://www.broadinstitute.org/ \\
\hline & 5 & A6300 & $\mathrm{H}$ & 1 & NZ ACKF00000000 & http://www.broadinstitute.org/ \\
\hline & 5 & A8115 & $\mathrm{H}$ & $\mathrm{S}$ & $\underline{\mathrm{NZ}}$ ACKG00000000 & http://www.broadinstitute.org/ \\
\hline & 5 & A8117 & $\mathrm{H}$ & $\mathrm{s}$ & $\underline{\mathrm{NZ}} \mathrm{ACY} 000000000$ & http://www.broadinstitute.org/ \\
\hline & 5 & A9719 & $\mathrm{H}$ & $U$ & NZ ACKJ00000000 & http://www.broadinstitute.org/ \\
\hline & 5 & A9763 & $\mathrm{H}$ & $\mathrm{U}$ & $\underline{\mathrm{NZ}}$ ACKK00000000 & http://www.broadinstitute.org/ \\
\hline & 5 & A9781 & $\mathrm{H}$ & U & NZ ACKL00000000 & http://www.broadinstitute.org/ \\
\hline & 5 & A9299 & $\mathrm{H}$ & $\mathrm{U}$ & $\underline{\mathrm{NZ}} \mathrm{ACKH} 00000000$ & http://www.broadinstitute.org/ \\
\hline & 5 & A10102 & $\mathrm{H}$ & $u$ & $\underline{\mathrm{NZ}}$ ACSO000000000 & http://www.broadinstitute.org/ \\
\hline & 5 & CF-Marseille & $\mathrm{H}$ & 1 & NZ CABA00000000 & {$[50]$} \\
\hline & 5 & ED98* & $A$ & 1 & $\underline{\mathrm{CP} 001781}$ & {$[20]$} \\
\hline & 5 & Mu3* & $\mathrm{H}$ & 1 & AP009324 & {$[51]$} \\
\hline & 5 & Mu50* & $\mathrm{H}$ & I & $\underline{B A 000017}$ & {$[52]$} \\
\hline & 5 & N315* & $\mathrm{H}$ & $\mathrm{s}$ & $\underline{\mathrm{BA} 000018}$ & {$[52]$} \\
\hline & 105 & $\mathrm{JH} 1^{*}$ & $\mathrm{H}$ & 1 & CP000736 & [53] \\
\hline & 105 & $\mathrm{JH} 9^{*}$ & $\mathrm{H}$ & 1 & $\underline{\mathrm{CP} 000703}$ & {$[53]$} \\
\hline 7 & 7 & USA300 TCH959* & $\mathrm{H}$ & $\mathrm{S}$ & NZ AASB00000000 & http://www.ncbi.nlm.nih.gov \\
\hline \multirow[t]{7}{*}{8} & 8 & A5948 & $\mathrm{H}$ & U & NZ ACKD00000000 & http://www.broadinstitute.org/ \\
\hline & 8 & A9765 & $\mathrm{H}$ & $\mathrm{U}$ & NZ ACSN00000000 & http://www.broadinstitute.org/ \\
\hline & 8 & NCTC $8325^{*}$ & $\mathrm{H}$ & $\mathrm{S}$ & $\underline{\mathrm{CP} 000253}$ & {$[54]$} \\
\hline & 8 & Newman* & $\mathrm{H}$ & 1 & $\underline{\text { AP009351 }}$ & {$[55]$} \\
\hline & 8 & USA300 FPR3757* & $\mathrm{H}$ & I & $\underline{\mathrm{CP} 000255}$ & {$[56]$} \\
\hline & 8 & USA300 TCH1516* & $\mathrm{H}$ & $S$ & CP000730 & {$[57]$} \\
\hline & 250 & $\mathrm{COL}^{*}$ & $\mathrm{H}$ & $\mathrm{S} ?$ & $\underline{\mathrm{CP} 000046}$ & {$[58]$} \\
\hline \multirow[t]{2}{*}{10} & 10 & $\mathrm{H} 19$ & $\mathrm{H}$ & U & NZ ACSS 00000000 & http://www.broadinstitute.org/ \\
\hline & 145 & D139 & $\mathrm{H}$ & U & $\underline{\mathrm{NZ}}$ ACSR 00000000 & http://www.broadinstitute.org/ \\
\hline 22 & 22 & EMRSA15/5096* & $\mathrm{H}$ & 1 & & http://www.sanger.ac.uk/pathogens \\
\hline \multirow[t]{6}{*}{30} & 30 & $55 / 2053$ & $\mathrm{H}$ & $U$ & $\underline{\text { NZ ACJR00000000 }}$ & http://www.broadinstitute.org/ \\
\hline & 30 & $58-424$ & $\mathrm{H}$ & U & NZ ACUT00000000 & http://www.broadinstitute.org/ \\
\hline & 30 & $65-1322$ & $\mathrm{H}$ & $\mathrm{U}$ & $\underline{\mathrm{NZ} \text { ACJS00000000 }}$ & http://www.broadinstitute.org/ \\
\hline & 30 & $68-397$ & $\mathrm{H}$ & $\mathrm{U}$ & NZ ACJT00000000 & http://www.broadinstitute.org/ \\
\hline & 30 & A017934/97 & $\mathrm{H}$ & $\mathrm{U}$ & NZ ACYP00000000 & http://www.broadinstitute.org/ \\
\hline & 30 & Btn1260 & $\mathrm{H}$ & $U$ & NZ ACUU00000000 & http://www.broadinstitute.org/ \\
\hline
\end{tabular}


Table 1: Sequenced Staphylococcus aureus genomes (Continued)

\begin{tabular}{|c|c|c|c|c|c|c|}
\hline & 30 & C101 & $\mathrm{H}$ & $U$ & NZ ACSP00000000 & http://www.broadinstitute.org/ \\
\hline & 30 & E1410 & $\mathrm{H}$ & $\mathrm{U}$ & NZ ACJU00000000 & http://www.broadinstitute.org/ \\
\hline & 30 & M1015 & $\mathrm{H}$ & $\mathrm{U}$ & NZ ACST00000000 & http://www.broadinstitute.org/ \\
\hline & 30 & M876 & $\mathrm{H}$ & $U$ & $\underline{\mathrm{NZ}}$ ACJV00000000 & http://www.broadinstitute.org/ \\
\hline & 30 & M899 & $\mathrm{H}$ & $\mathrm{U}$ & NZ ACSU00000000 & http://www.broadinstitute.org/ \\
\hline & 30 & MN8 & $\mathrm{H}$ & $\mathrm{S}$ & $\underline{\mathrm{NZ}} \mathrm{ACJ} A 00000000$ & http://www.ncbi.nlm.nih.gov \\
\hline & 30 & $\mathrm{TCH} 60$ & $\mathrm{H}$ & $\mathrm{S}$ & $\mathrm{NZ}$ ACHC00000000 & http://www.ncbi.nlm.nih.gov \\
\hline & 30 & WBG10049 & $\mathrm{H}$ & V & NZ ACSV00000000 & http://www.broadinstitute.org/ \\
\hline & 30 & WW2703/97 & $\mathrm{H}$ & $\mathrm{U}$ & NZ ACSW00000000 & http://www.broadinstitute.org/ \\
\hline & 34 & $\mathrm{C} 160$ & $\mathrm{H}$ & $\mathrm{U}$ & NZ ACUV00000000 & http://www.broadinstitute.org/ \\
\hline & 36 & MRSA252* & $\mathrm{H}$ & 1 & $\underline{B \times 571856}$ & {$[48]$} \\
\hline 42 & 42 & C427 & $\mathrm{H}$ & $\mathrm{U}$ & NZ ACSQ00000000 & http://www.broadinstitute.org/ \\
\hline 45 & 45 & A9635 & $\mathrm{H}$ & U & NZ ACKI00000000 & http://www.broadinstitute.org/ \\
\hline 72 & 72 & $\mathrm{TCH} 130$ & $\mathrm{H}$ & S & $\underline{\mathrm{NZ}}$ ACHD00000000 & http://www.ncbi.nlm.nih.gov \\
\hline 151 & 151 & RF122/ET3-1* & B & I & $\underline{\text { AJ938182 }}$ & {$[59]$} \\
\hline \multirow[t]{3}{*}{239} & 239 & JKD6008 & $\mathrm{H}$ & I & NZ ABRZ00000000 & http://www.ncbi.nlm.nih.gov \\
\hline & 239 & JKD6009 & $\mathrm{H}$ & 1 & $\underline{N Z \text { ABSA00000000 }}$ & http://www.ncbi.nlm.nih.gov \\
\hline & 239 & 0582/TW20* & $\mathrm{H}$ & 1 & FN433596 & http://www.sanger.ac.uk/pathogens \\
\hline 398 & 398 & S0385* & $\mathrm{P} / \mathrm{H}$ & 1 & $\underline{\text { AM990992 }}$ & http://www.ncbi.nlm.nih.gov \\
\hline 425 & 425 & LGA251* & B & 1 & & http://www.sanger.ac.uk/pathogens \\
\hline 431 & 431 & M809 & $\mathrm{H}$ & $\mathrm{U}$ & NZ ACUS00000000 & http://www.broadinstitute.org/ \\
\hline
\end{tabular}

higher levels of interlineage variation in the $\mathrm{N}$ terminus of IsaB, SasC and SasF, in comparison to the $C$ terminus. Intralineage amino acid variation is present in all surface bound proteins. Low levels of variation (proportion of variable sites $<0.05$ ) exist in 22 surface proteins, whilst $\mathrm{SdrD}$, Spa and SraP have higher levels of intralineage variation. Across all proteins there are small levels of intralineage variation in host-interface domains (proportions of variable amino acid sites vary from 0.000 to 0.078 ) (Additonal file 1 Table S1). Interestingly, intralineage levels of variation differ between lineages in host-interface domains of a small subset of surface bound proteins. For example, the FN-1 binding domain of FnBPA has a proportion of variable amino acid sites of $0.032,0.016$ and
0.008 for CC5, CC8 and CC30 respectively, whilst there is an interlineage variation of 0.139 . Such variation could support $S$. aureus lineage adaption to hosts and environments, and/or $S$. aureus evasion of the host immune response.

An example of a highly variable surface protein is FnBPA. The distribution of protein domain variants of FnBPA across CC lineages shows evidence of recombination. (Additonal file 3 Table S3). For the purposes of this paper we define a domain variant as any domain with a sequence encoding one amino acid difference. In addition, we define a domain that has greater than $5 \%$ of variable amino acids as a major variant within a domain. The data shows that a range of major and/or minor sequence 
Table 2: Abbreviation list of Staphylococcus aureus genes/proteins

\begin{tabular}{|c|c|c|c|}
\hline Protein name & Gene symbol & Protein symbol & Published reference \\
\hline Autolysin/adhesin from S. aureus & $a a a$ & Aaa & {$[60]$} \\
\hline Clumping factor $A$ & clfA & ClfA & [61-63] \\
\hline Clumping factor $B$ & $C l f B$ & ClfB & {$[64,65]$} \\
\hline Chemotaxis inhibitory protein of Staphylococcus aureus & chp & $\mathrm{CHIP}$ & [39] \\
\hline Collagen adhesin & cna & Cna & [66-68] \\
\hline Coagulase & coa & Coa & {$[69,70]$} \\
\hline Extracellular adhesion protein & eap & Eap & [71-73] \\
\hline ECM-binding protein homologue & $e b h$ & Ebh & [74-77] \\
\hline Elastin-binding protein of Staphylococcus aureus & ebps & EbpS & [78-80] \\
\hline Extracellular complement-binding protein & $e c b$ & Ecb & [11] \\
\hline Extracellular fibrinogen-binding protein & efb & Efb & [81-83] \\
\hline Extracellular matrix protein & emp & Emp & {$[84]$} \\
\hline ESAT-6 secretion accessory $C$ & esaC & EsaC & {$[85,86]$} \\
\hline ESAT-6 like factor A & esxA & EsxA & [86] \\
\hline ESAT-6 secretion system C & essC & EssC & {$[86]$} \\
\hline FPR-like1 inhibitory protein & fll & FLIPr & [10] \\
\hline FPR-like1 inhibitory protein like & flr & FLIPr-like & {$[11]$} \\
\hline $\begin{array}{l}\text { Factor which affects the methicillin resistance level and autolysis in } \\
\text { the presence of Triton X-100 B }\end{array}$ & $f m t B$ & FmtB & {$[24,87]$} \\
\hline Fibronectin binding protein $\mathrm{A}$ & fnbpA & FnBPA & {$[24,88-93]$} \\
\hline Fibronectin binding protein $\mathrm{B}$ & $f n b p B$ & FnBPB & [89] \\
\hline Immunodominant surface antigen $B$ & is $a B$ & IsaB & [94] \\
\hline Iron-regulated surface determinants A & isd $A$ & IsdA & {$[9,95-97]$} \\
\hline
\end{tabular}


Table 2: Abbreviation list of Staphylococcus aureus genes/proteins (Continued)

\begin{tabular}{|c|c|c|c|}
\hline Iron-regulated surface determinants B & $i s d B$ & IsdB & {$[9,96]$} \\
\hline Iron-regulated surface determinants $\mathrm{H}$ & $i s d H$ & IsdH & {$[9,97,98]$} \\
\hline Penicillin-binding protein 2a conferring resistance to methicillin & mecA & MecA & \\
\hline Staphylokinase & sak & SAK & [39] \\
\hline Staphylococcus aureus protein B & $\operatorname{sas} B$ & SasB & [87] \\
\hline Staphylococcus aureus protein C & $\operatorname{sas} C$ & SasC & {$[23,99]$} \\
\hline Staphylococcus aureus protein D & $\operatorname{sas} D$ & SasD & {$[22]$} \\
\hline Staphylococcus aureus protein F & sas $F$ & SasF & {$[22,100]$} \\
\hline Staphylococcus aureus protein $\mathrm{G}$ & sasG & SasG & {$[22,101,102]$} \\
\hline Staphylococcus aureus protein $\mathrm{H}$ & sasH & SasH & {$[22,103]$} \\
\hline Staphylococcus aureus protein $\mathrm{K}$ & sask & Sask & [22] \\
\hline Staphylococcus aureus binder of lgG & $s b i$ & Sbi & {$[12,104,105]$} \\
\hline Staphylococcal complement inhibitor & $s c n$ & SCIN & [39] \\
\hline Staphylococcal complement inhibitor B & $\operatorname{scin}-B$ & SCIN-B & [11] \\
\hline Staphylococcal complement inhibitor $C$ & $\operatorname{scin}-\mathrm{C}$ & SCIN-C & [11] \\
\hline Serine aspartate repeat protein $C$ & $s d r C$ & $\mathrm{SdrC}$ & {$[106,107]$} \\
\hline Serine aspartate repeat protein $\mathrm{D}$ & $s d r D$ & SdrD & [106-109] \\
\hline Serine aspartate repeat protein $\mathrm{E}$ & sdrE & SdrE & [106] \\
\hline Staphylococcus aureus protein A & spa & Spa & [110-112] \\
\hline Serine-rich adhesin for platlets & sraP & SraP & {$[113,114]$} \\
\hline von Willebrand factor-binding protein & $v w b$ & VWbp & {$[115-117]$} \\
\hline
\end{tabular}

variations exist for the $\mathrm{N}$ terminus of the variable region domain, the fibrinogen (FG) and elastin (ELN) binding domain and the fibronectin (FN-1) binding domain (Additonal file 3 Table S3). Within each CC lineage only one major sequence variant exists for each FnBPA domain, and therefore the whole gene is lineage-specific. Surprisingly, the same major sequence variant of a domain is often found in unrelated lineages. Furthermore, whilst a lineage may share a major sequence variant of one domain with one unrelated lineage, it may share a major sequence variant at an adjacent domain with a different unrelated lineage. This shows that the fnbpA gene has a mosaic structure and indicates the fnbpA locus is evolving through recombination, in addi- 
tion to point mutation. Loughman et al. [24] have previously identified FnBPA sequence variants from human strains of lineages that have not had their genome sequenced (CC12, CC15, CC25, CC55, CC59, CC101, CC121 and CC509) and classified seven isotypes. They have shown that all isotypes have human fibrinogen binding activity, but that isotype I (found in $\mathrm{CC} 8, \mathrm{CC} 15$ and CC55) binds weakly to elastin. Inclusion of these partial gene sequences [GenBank: AM749006-15], corresponding to amino acid residues 1- 565, in our analysis suggests these gene variants are typical. Interestingly, they prove that no animal $S$. aureus strain has a major domain variant that is not found in a human $S$. aureus lineage. The bovine strain LGA25 1 (CC425) shares a major variant of the FG and ELN binding domain with human strains TCH959 (CC7) and 3110 (CC 12). Likewise, bovine strain RF122 (CC151) has a major variant of the FG and ELN binding domain that is also found in strains D139 and H19 (both CC10). Porcine strain S0385 (CC398) shares a major variant of the FG and ELN binding domain with human strain 3153 (CC509), varying at only 11 amino acid residues. The $\mathrm{N}$ terminus of the variable region of these three strains is a recombination of sequences found in a range of human S. aureus lineages. This indicates that animal S. aureus lineages have domain variants also found in human $S$ aureus lineages.

Interestingly, animal lineages possess a unique combination of FnBPA domain variants that are not found in human lineages (Additonal file 3 Table S3). A unique combination of domain variants is also found in animal isolates in other surface bound proteins (ClfA, Eap, Ebh, EbpS, IsdB, SdrD and SdrE). In addition, novel domain variants are found in animal lineages in other surface bound proteins (FnBPB, IsdA, IsdH and SasB). Interestingly, much of this novel domain variation has been generated by intradomain recombination events. These proteins could be important in the adaptation of S. aureus to different host species. Determining whether animal lineages truly have a unique domain variant or possess a unique combination of domain variants can only truly be resolved by future sequencing of other major human $S$. aureus lineages, or through future microarray studies. For other surface proteins, animal lineages do not have a unique combination of domain variants, and neither do they possess unique domain variants (Aaa, ClfB, Cna, IsaB, SasC, SasF, SasG, SasH, SasK, SdrC, Spa and SraP). This therefore questions the importance of these genes in the adaptation of $S$. aureus lineages to different host species.

\section{Sequence variation in secreted $\mathrm{S}$. aureus proteins}

The sequence variation of 13 secreted $S$. aureus genes encoding proteins that have characterised or hypothesised roles in immune evasion was analysed (Additonal file 2 Table S2). Eight (coa, ecb, efb, emp, esxA, essC, sbi and $v w b p$ ) of the 13 secreted genes are present in all sequenced $S$. aureus genomes. In addition, each genome either possesses a gene encoding FLIPr or FLIPr-like and SCIN-B or SCIN-C suggesting that the function of these homologs is essential to $S$. aureus survival and replication (Additonal file 2 Table S2). As functions of all these proteins, except EsaC, are present in all sequenced genome this suggests that secreted proteins involved in immune evasion are critical to $S$. aureus.

All 13 secreted proteins are variable amongst $S$. aureus genomes (Additonal file 2 Table S2). There is a higher level of interlineage variation in host interface domains than other domains for Coa and vWbp. In Efb there is greater variation in the signal sequence than domain characterised in host interactions. Sbi has a characterised host- interface domain, yet there is more variation in the $\mathrm{C}$ terminus (proportion of variable residues $=0.251$ ) than the Ig or C3 binding domains (proportion of variable residues ranges from 0.000 to 0.125 ). Functional domains are currently unidentified for Ecb, Emp, EsaC, EsxA, EssC, FLIPr, FLIPr-like, SCIN-B and SCIN-C.

Intralineage variation is present in $\mathrm{Coa}, \mathrm{Efb}, \mathrm{Emp}, \mathrm{EssC}$, FLIPr, Sbi and VWbp at low levels (proportion of variable sites $<0.019$ ) and absent in the remaining proteins. The exception is FLIPr-like which is more variable and frequently truncated. The level of and location of intralineage variation differs between the CC5, CC 8 and CC30 lineages. The secreted proteins involved in immune evasion of $S$. aureus lineages may be differentially adapted, but that there was little adaptation of strains within lineages.

An example of a highly variable immune evasion gene, coa or coagulase, is shown in more detail in additonal file 4 Table S4. There are a variety of conserved domains spread amongst the lineages. Similarly to FnBPA, unrelated lineages often share the same domain variants (Additonal file 4 Table S4). However, there is less evidence of recombination within the coa gene than within the $f n b p A$ gene as there are fewer examples of unrelated lineages sharing the same sequence variant. An exception to this is the C terminus. The pig CC398 coa gene is highly similar to the human CC45 coa gene. The avian CC5 strain has the same gene as the human CC5. The bovine CC425 is similar to human CC5 genes but has a different central region, while the bovine CC151 strain has a unique coa gene.

Animal lineages possess unique combinations of Coa domain variants that are not found in human lineages, similar to FnBPA (Additonal file 4 Table S4). Animal lineages also have a unique combination of domain variants for other secreted proteins (Emp and VwBP). Animal lineages possess unique domain variants in EssC, SCIN-B and VwBP, whilst for other secreted proteins (Ecb, Efb, 
Table 3: Abbreviation list of host genes/proteins used in the manuscript

\begin{tabular}{|c|c|c|}
\hline Protein name & Gene symbol & $\begin{array}{l}\text { Protein } \\
\text { symbol }\end{array}$ \\
\hline Complement protein 3 & & $\mathrm{C} 3$ \\
\hline C3 convertase & & C4b2a \\
\hline Collagen type 1 & & $\mathrm{CN}-1$ \\
\hline Cytokeratin 10 & & CK10 \\
\hline Elastin & emn & ELN \\
\hline Fibirogen & $f g a, f g b, f g g$ & FGA, FGB, FGG \\
\hline Fibronectin & $f n-1$ & $\mathrm{FN}-1$ \\
\hline $\begin{array}{l}\text { Formyl peptide } \\
\text { receptor }\end{array}$ & & FPR \\
\hline FPR-Like-1 & & FPRL1 \\
\hline Haemoglobin & & $\mathrm{Hb}$ \\
\hline Haptoglobin & & $\mathrm{Hp}$ \\
\hline Immunogblubin G & & $\lg G$ \\
\hline $\begin{array}{l}\text { Tumour necrosis factor } \\
\text { receptor } 1\end{array}$ & & TNRF1 \\
\hline Thrombospondin 1 & & TSP-1 \\
\hline Vitronectin & $v t n$ & VN \\
\hline Prothrombin & $p t$ & PT \\
\hline Von Willebrand factor & $v w f$ & vWF \\
\hline
\end{tabular}

EsaC, EsxA, FLIPr, FLIPr-like, SCIN-C and Sbi) animal lineages do not have unique domain variants or a unique combination of domain variants.

\section{Microarray data}

Microarray data is useful for confirming the distribution of genes amongst large populations, for showing that lineages are conserved, and investigating unsequenced lineages. Using the seven-strain $S$. aureus microarray the 400 isolates, representing MSSA, HA-MRSA, CA MRSA and from human, bovine, equine, pig, goat, sheep and camel, clustered into 20 dominant lineages. The distribution of surface and secreted gene variants is shown in Fig. 1 , and confirms that all strains of a lineage usually carry the same distribution of surface and immune evasion genes and variants, and that variants are often distributed across unrelated lineages. The distribution of genes with poorly performing spots (eap, ebpS, emp, esaC, scin-c and $v w b p$ ) and genes with spots that do not discriminate lineage-specific variation (clfA, clfB, ecb, efb, EsxA, essC, isdA, isdB, isdC, isdH, sasB, sasF, sasH, sasK, sbi, sdrC, spa and sraP) are not reported in this microarray study. Some gene variants are not included in the microarray design as they were not identified in the first seven $S$. aureus whole genome sequencing projects [25].

\section{Variation in host ligands of $\mathrm{S}$. aureus proteins}

The location of and proportion of amino acid variable sites for human ligands are shown in Table 4. Variation is present in each of the ligands analysed. Notably, the proportion of variable residues is high $(>0.015)$ in the $\beta$ chain (FGB) and $\gamma$-chain (FGG) of fibrinogen, and in elastin (ELN). Lower levels of variation exist in the $\alpha$-chain (FGA) of fibrinogen $(0.010)$, promthrombin (PT) (0.006), vitronectin $(\mathrm{VN})(0.006)$, fibronectin (FN-1) (0.006) and the von Willebrand factor (vWF) (0.008). This analysis shows that the amino acid sequence in $S$. aureus ligands varies in humans, and some of this variation is in domains interacting with ClfA, ClfB and FnBPA. This could provide a selective pressure for the evolution and adaptation of $S$. aureus adhesins in human populations.

The interspecies similarity of host ligands was calculated for FGB, FGG, FN-1, PT and vWF (Additonal file 5 Tables S5-S9). Species included in analysis are those for which full sequence is available and annotated. For FGA, ELN and VTN there was too much variation amongst interspecies sequences to construct a reliable alignment. Interspecies similarity matrices are therefore not reported for these ligands. For fibrinogen the analysis shows that considerable variation exists in both FGB and FGG between humans and other animal species that become colonised with $S$. aureus, such as dog, cow and horse (Additonal file 5 Tables S5 and S6). Interestingly, FGB (similarity $=79.1 \%$ ) has a lower similarity score for human and cow homologs than FGG (similarity $=83.7 \%$ ) revealing that levels of interspecies variation differ between chains of complexes for this species pair. Surprisingly, the animal species that has the lowest identity to human sequence varies amongst the ligands. For example, the similarity of human vWF to that of pig and cow is 0.559 and 0.810 respectively, whilst the similarity of human PT to that of pig and cow is 0.828 and 0.812 respectively (Additonal file 5 Tables S8 and S9). This analysis shows that there is a substantial interspecies vari- 
ation in host ligands that consequently will provide a selective pressure for the adaptation of $S$. aureus adhesins.

\section{Discussion}

The multitude of sequencing projects available in the last year has confirmed previous observations about $S$. aureus population structure but also revealed some new surprises. In this manuscript we have focussed specifically on those proteins that are predicted to interact with host because of their importance in vaccine development, but also because they are presumed to define the host-pathogen interaction.

Our analysis proves that variation in genes encoding surface proteins is lineage specific, but that many domain variants are conserved across unrelated lineages. Most of the variation occurs in predicted functional domains. Many are missing in some lineages, or are frequently truncated. Similarly, the genes encoding secreted proteins predicted to interact with host immune responses also show variation that is lineage specific, conserved across unrelated lineages, and occurs in predicted functional domains. The amount of variation in immune evasion genes is less than in the surface proteins, and missing or truncated proteins are less common.

The surface proteins are major targets for vaccine development. Vaccines to ClfA, ClfB, FnBPA, IsdA, IsdB, SdrD, SdrE, Eap, Emp have shown protection in animal models as have capsule and haemolysin A [26-32]. The animal model work typically involves vaccinating against one surface protein variant, and then exposing the animals to a challenge strain expressing the same surface protein variant. Human trials of capsule vaccines to prevent infection or colonisation have been disappointing $[33,34]$. A trial of a vaccine to enhance ClfA antibody produced sera that did not protect low birth-weight babies from sepsis [35]. Furthermore, commercial vaccines for livestock are generally not effective [36]. Yet, S. aureus surface proteins are currently in human vaccine trials.

Humans are exposed to a variety of $S$. aureus lineages. This paper clearly shows that $S$. aureus populations carry a range of unique variants of surface proteins. Therefore, animals in vaccine trials should be challenged with a range of $S$. aureus lineages so that the vaccine is tested with a representative range of $S$. aureus surface proteins. If the vaccine is protective against a range of strains, it may then be suitable for human trials. Vaccines cocktails of multiple surface proteins have been tested in animals [27]. However, these also use the variants found in only one laboratory lineage. To obtain good coverage, multiple variants of multiple targets in the vaccine cocktail will likely be more effective. The lack of variant antigens in the vaccines currently tested in animals, humans and livestock may explain their failure to protect from infection with naturally occurring $S$. aureus populations in the non-laboratory environment.

We note that MRSA strains in our collection typically had the same surface and secreted protein profiles as methicillin-sensitive Staphylococcus aureus (MSSA) from the same lineage. We did not find a surface or secreted immune marker of MRSA, nor of HA-MRSA or CAMRSA strains.

If a surface protein is dispensable in some lineages that are still able to cause disease, then its role in virulence is called into question. Many surface proteins appear to bind multiple host proteins, and multiple surface proteins may bind the same host protein [9]. Therefore, the role of individual proteins in disease is difficult to prove and it seems likely that a combination of proteins is essential for virulence. Intriguingly, some lineages are thought to be more associated with particular human hosts than others [37]. We can show there are subtle variations in the genetic sequences of human host proteins, especially in binding regions, which may be implicated in this host specificity.

Unexpectedly, the sequences of the animal lineages of $S$. aureus do not support this hypothesis. If animal strains of $S$. aureus interact with animal host proteins the bacteria would be expected to have animal specific binding proteins or domains. However this is generally not the case, and the animal strains show gene sequences remarkably similar to those found in human strains. No unique surface proteins with an LPxTG anchoring domain could be identified in any of the animal sequencing projects [38]. Yet, the sequence of predicted animal protein targets is substantially different from human counterparts. How do S. aureus strains interact specifically with non-human hosts? The importance of individual proteins in hostpathogen interactions is therefore difficult to confirm.

One factor that is not taken into account in this study is the possibility of strains acquiring additional genes on mobile genetic elements (MGEs). Indeed, we have previously shown that a bacteriophage of the phi3 family is found in most human isolates of $S$. aureus but in only about $20 \%$ of animal strains [14]. This phage frequently carries genes encoding human specific immune evasion proteins chemotaxis inhibitory protein (chip), staphylococcal complement inhibitor (scin, (unique from $\sin -B$ and scin-C) and staphylokinase (sak) [39]. Our analysis of the animal $S$. aureus strain genome sequences did not identify any novel MGE genes with a possible surface or immune evasion function. Although it is true that novel immune evasion genes can be difficult to identify from sequence alone, and some may be characterised in the future. The distribution of these genes among large populations awaits large scale comparative genomics studies using sequencing or extended microarray platforms.

The fact that surface and immune evasion proteins varied predominantly in predicted functional regions sug- 


\begin{tabular}{|c|c|c|c|c|c|c|c|c|c|c|c|c|c|c|c|c|c|c|c|c|c|}
\hline \multirow{2}{*}{ Gene } & \multirow[t]{2}{*}{ Identifier } & \multicolumn{20}{|c|}{ Lineage } \\
\hline & & & $\begin{array}{l}5 \\
{ }_{*}+ \\
+\end{array}$ & $\begin{array}{l}8 \\
{ }_{+}^{+}\end{array}$ & 12 & 15 & ${ }_{*}^{22}$ & 25 & $\begin{array}{l}30 \\
{ }^{*}+\end{array}$ & 45 & 51 & 59 & 80 & 97 & 130 & ${ }_{*}^{151}$ & 188 & 239 & 398 & 771 & 873 \\
\hline MRSA & & c & $\mathrm{H}$ & $\mathrm{CH}$ & & & $\mathrm{H}$ & & $\mathrm{H}$ & $\mathrm{H}$ & & C & C & & & & & & & $\mathrm{CH}$ & \\
\hline Host & & hbe & $\mathrm{h}$ & hbe & $\mathrm{h}$ & $\mathrm{h}$ & he & $\mathrm{h}$ & h & $\mathrm{h}$ & $\mathrm{h}$ & $\mathrm{h}$ & $\mathrm{h}$ & $\mathrm{hb}$ & $\mathrm{hb}$ & b & $\mathrm{hb}$ & $\mathrm{h}$ & $\mathrm{hp}$ & $b$ & $b$ \\
\hline cna & R-2274 & & & & & & & & & & & & & & & & & & & & \\
\hline fnbpa & $\mathrm{R}-2580 \mathrm{v}$ & & & & & & & & & & & & & & & & & & & & \\
\hline fnbpA & $\mathrm{N}-2291 \mathrm{v}$ & & & & & & & & & & & & & & & & & & & & \\
\hline fnbpA & $8-3446$ & & & & & & & & & & & & & & & & & & & & \\
\hline$f n b p B$ & $\mathrm{~N}-2290 \mathrm{v}$ & & & & & & & & & & & & & & & & & & & & \\
\hline fnbpB & $8-3444$ & & & & & & & & & & & & & & & & & & & & \\
\hline is $a B$ & R-2717 & & & & & & & & & & & & & & & & & & & & \\
\hline sasC & R-1841 & & u & & & & & & & & & & & & & & & & & & \\
\hline sasD & R-0136 & & & & & & & & & & & & & & & & & & & & \\
\hline sas $G$ & $\mathrm{~N}-2285$ & & & & & & & & & & & & & & & & & & & & \\
\hline$s d r D$ & $\mathrm{~N}-0519 \mathrm{v}$ & & & & & & & & & & & & & & & & & & & & \\
\hline$s d r E$ & $\mathrm{~N}-0520 \mathrm{v}$ & & & & & & & & & & & & & & & & & & & & \\
\hline coa & $\mathrm{N}-0222 \mathrm{v}$ & & u & & & & & & & & & & & & & & & & & & \\
\hline coa & $\mathrm{M}-0206 \mathrm{v}$ & & & & & & & & & & & & & & & & & & & & \\
\hline coa & $\mathrm{R}-0222 \mathrm{v}$ & & & & & & & & & & & & & & & & & & & & \\
\hline coa & $8-0239 v$ & & & & & & & & & & & & & & & & & & & & \\
\hline flipr & $\mathrm{N}-1001$ & & & & & & & & & & u & & & & $\mathrm{u}$ & & & & & & \\
\hline
\end{tabular}

Figure 1 Microarray analysis. Microarrays show gene variants are conserved across unrelated lineages. Genes are listed in order by name and by their annotated gene number prefixed with the strain that was used as the template for the PCR probe on the microarray (R, MRSA252; N, N315; 8 , 8325; M, MW2; U, Mu50). A black box indicates the gene or gene variant is present in that lineage. '*' indicates the genome of a strain from this lineage has been sequenced. ' + ' indicates ORFs from this lineage are included on the 7 strain microarray. C indicates community associated MRSA were included, and $\mathrm{H}$ indicates hospital associated MRSA were included. Strains from the following hosts were included: $h$, human, b, bovine, e, equine, $p$, pig. 'v' denotes a PCR product designed to a specific variant region. 'u' indicates variation in gene distribution for that lineage.

gests these proteins do play a role in host interaction and that variants have been selected for. Loughman et al. [24] have investigated seven variants (isotypes) of the FnBPA protein for their ability to bind human fibrinogen and elastin. All variants bound fibrinogen equally well, but one variant bound elastin less efficiently. The fact that all the variants had activity supports the idea that FnBPA does indeed play a role in host-pathogen interaction as presumably variants that do not bind are not selected for. But it is also interesting that elastin binding could be dispensable. Jongerius et al. [11] have shown that SCIN-B and SCIN-C are unable to inhibit AP-mediated hemolysis in serum of species other than humans. They also showed that Ecb and Efb blocked complement of human and 7 other species. Therefore, the function of all variants against all hosts cannot be assumed until appropriate biological studies are performed.

Although human and animal lineages have been well described, some human strains do cause infection in animals and vice versa $[4,12,40]$. If specific host-pathogen interactions are necessary, then perhaps each strain carries one or more key surface and immune evasion proteins that are specific to each of the animal species they colonise. Alternatively, some bacterial proteins may interact with a broad host range. Biological studies to investi- gate these hypotheses across a broad range of surface and immune evasion proteins are needed.

While 58 genomes are currently available for analysis, there are still many lineages of $S$. aureus that have not been sequenced. This is likely to change in the next few years. However, our analysis suggests that the majority of genes on the stable core and lineage specific regions of the genome may have been sequenced already, and few very different genes or gene variants will be described. The exceptions may be in fnbpA and coa which seem to be remarkably variable and frequently recombining. Single nucleotide polymorphisms and variable repeat regions in genes (Additonal file Table $\mathrm{S} 1$ and additional 2 Table S2) are also expected to continue to evolve and vary. New genomes may reveal new surprises, and often identify new MGEs [41].

\section{Conclusions}

In summary, the similarity of surface and immune evasion genes in S. aureus strains from different animal hosts with very different target proteins is surprising and suggests specific host-pathogen interactions via these proteins are not essential for virulence. However, variation in $S$. aureus proteins is predominantly in predicted functional regions and there is some biological evidence that 
Table 4: Variation in human proteins

\begin{tabular}{|c|c|c|c|c|c|}
\hline Ligand & Gene & NCBIGenelD & Variable amino acid sites & $\begin{array}{l}\text { Proportion of } \\
\text { variable sites }\end{array}$ & $\begin{array}{l}\text { Characterised interacting } \\
\text { S. aureus protein(s) }\end{array}$ \\
\hline Elastin & eln & 2006 & $\begin{array}{l}40,71,165,298,311,398,422 \\
463,494,503,544,581,651,711\end{array}$ & 0.019 & EbpS, FnBPA \\
\hline \multirow[t]{3}{*}{ Fibrinogen/Fibrin } & fga & 2243 & $6, \mathbf{3 3} 1^{\mathbf{b}}, 392,446,456,507,729$ & 0.010 & ClfB, FnBPB, Ebh, IsdA, \\
\hline & $f g b$ & 2244 & $2,86,100,170,192,265,398,478$ & 0.016 & Efb, \\
\hline & fgg & 2266 & $\begin{array}{l}12,14,25,54,77,87 \\
89,113,114,132,140,177,191 \\
219,410^{\text {ac }}\end{array}$ & 0.033 & ClfA, FnBPA \\
\hline Fibronectin & $f n-1$ & 2335 & $\begin{array}{l}15, \mathbf{2 5 1 c}, 352,759,817 \\
984,1044,1103,1558,2195,2212 \\
2261,2275,2281\end{array}$ & 0.006 & FnBPA, FnBPB, \\
\hline Prothrombin & $f 2$ & 2147 & $165,200,272,386$ & 0.006 & VWbp \\
\hline Vitronectin & $v t n$ & 7448 & $122,268,400$ & 0.006 & Unknown protein [118] \\
\hline $\begin{array}{l}\text { von Willebrand } \\
\text { factor }\end{array}$ & $v w f$ & 7450 & $\begin{array}{l}\text { 137, 318, 325d, 471, 484, 653, } \\
740,817,852 \\
885,1380,1381,1435,1472,1565 \\
1569,2126,2178,2281,2342 \\
2561,2705\end{array}$ & 0.008 & VWbp Spa \\
\hline
\end{tabular}

variant bacterial proteins can have similar functions [24]. This argues that specific host-pathogen interactions of these proteins are essential for virulence. This is an area of research that requires further investigation. Importantly, vaccine development should utilise information on the variation, distribution and function of surface protein antigens amongst lineages to ensure that cocktails of gene variants are included. Otherwise vaccines may fail in human trials, and/or encourage selection of lineages different to those of laboratory strains, including CAMRSA.

\section{Methods \\ Staphylococcus aureus genomes}

Sequence data is available for the genomes of 58 Staphylococcus aureus isolates on the GenBank database http:// www.ncbi.nlm.nih.gov and the Broad Institute website http://www.broadinstitute.org/. The source and accession numbers of these genomes is shown in table 1. The genetic sequence of an additional $3 \mathrm{~S}$. aureus genomes was made available by Matt Holden (EMRSA-15 and LGA251; Sanger Centre, UK) and Ad Fluit (S0385; University Medical Centre Utrecht, Netherlands). Strains are of human origin except strain RF122 which is a bovine mastitis isolate, strain LGA25 1 from a bovine infection, strain ED98 from a diseased broiler chicken, and strain ST398 isolated from a human but likely from pig origin. Sequence analysis was therefore performed on the genomes of $58 \mathrm{~S}$. aureus isolates that represent 18 different multi locus sequence types (MLST) (ST1, ST5, ST7, ST8, ST22, ST30, ST34, ST36, ST42, ST45, ST72, ST105, ST145, ST151, ST239, ST250, ST398, ST425 and ST431) and 15 different clonal complex $(\mathrm{CC})$ lineages $(\mathrm{CC} 1, \mathrm{CC} 5$, CC7, CC8, CC10, CC22, CC30, CC42, CC45, CC72, CC151, CC239, CC398, CC425 and CC431) (Table 1). It should be noted that some of the genomes are not complete, and some may have minor errors that lead to the overestimation of truncated proteins.

\section{Sequence analysis of Staphylococcus aureus genes}

The sequence of each gene in a genome was first identified using the BLAST function of the GenBank database http://www.ncbi.nlm.nih.gov/blast. Sequences of a gene were subsequently aligned using the ClustalW program and then edited by hand if necessary in BioEdit $[42,43]$. Domains of $S$. aureus proteins were identified using the UniProt resource of protein sequence and function http:/ /www.uniprot.org and/or from previous literature. In cases where the domains of a protein have not previously been characterised, the signal sequence was identified using SignalP 3.0 and the remaining sequence was split into an $\mathrm{N}$-terminus and C- terminus [44].

The proportion of variable sites in each protein domain was calculated between all sequences available for each $S$. aureus gene, and is denoted as interlineage variation. The proportion of variable sites within protein domains was 
also calculated within $\mathrm{CC}$ lineages for $\mathrm{CC} 5, \mathrm{CC} 8$ and $\mathrm{CC} 30$, as these lineages had genome sequence available from multiple isolates (17, 7 and 18 isolates respectively). Within these CC lineages the extent of intralineage variation was calculated for ST5, ST8 and ST30, respectively. The extent of interlineage and intralineage variation in $S$. aureus proteins involved in adherence and nasal colonisation and/or immune modulation can therefore be compared.

\section{Microarray analysis}

A total of $400 \mathrm{~S}$. aureus isolates were analysed representing MSSA, HA-MRSA, CA MRSA and from human, bovine, equine, pig, goat, sheep and camel. The microarray used in this study was developed and comprehensively described previously [12,23]. Data from previous studies and additional strains from St George's Hospital Trust and kindly donated by Mark Enright are included $[12,14,40,45-47]$.

\section{Sequence analysis of host ligand genes}

The sequence of the human genes encoding fibrinogen (FG), fibronectin (FN), elastin (ELN), vitronectin (VN), prothrombin (PT) and von Willebrand factor (vWF) were isolated from the GenBank database, accession numbers are shown in Additonal file 3 Tables S3. Variable sites of each ligand were identified from the GenBank SNP resource http://www.ncbi.nlm.nih.gov/SNP and the proportion of variable sites was calculated.

The sequence of animal genes encoding fibrinogen (FG), fibronectin (FN-1) prothrombin (PT) and von Willebrand factor (vWF) were identified by BLAST search with human gene sequences and aligned in ClustalW program and then edited by hand if necessary in BioEdit $[42,43]$. GenBank accession numbers are shown in Additonal file 5 Tables S5-S9. A similarity matrix of sequences was calculated in BioEdit.

\section{Additional material}

Additional file $\mathbf{1}$ "Variation in S. aureus surface proteins". shows the inter- lineage and intra-lineage proportions of variable sites in protein domains for 24 Staphylococcus aureus adhesins.

Additional file $\mathbf{2}$ "Variation in S. aureus secreted proteins involved in immune evasion". shows the inter- lineage and intra-lineage proportions of variable sites in protein domains for13 Staphylococcus aureus secreted proteins involved in immune evasion.

Additional file 3 "Distribution of domain variants of FnBPA across $\boldsymbol{S}$. aureus lineages". shows the distribution of variants for each FnBPA domain is shown for 15 Staphylococcus aureus clonal complex lineages.

Additional file 4 "Distribution of domain variants of Coa across $S$. aureus lineages". shows the distribution of variants for each Coa domain is shown for15 Staphylococcus aureus clonal complex lineages.

Additional file $\mathbf{5}$ "Variation in host factors of $\boldsymbol{S}$. aureus". show the interspecies homology of host proteins in the form of a similarity matrix.

\section{Authors' contributions}

AJM participated in study design, generation of sequence alignments, sequence analysis, microarray analysis and in manuscript revisions. JAL participated in the study design and coordination, microarray analysis, and drafted the manuscript. All authors read and approved the final manuscript.

\section{Acknowledgements}

We are grateful to Jason Hinds, Kate Gould, Lucy Brooks, Denise Waldron, Adam Witney and Phil Butcher from the Bacterial Microarray Group at St George's

(BuG@S; http://www.bugs.sgul.ac.uk, funded by The Wellcome Trust, for assistance with all microarray studies. We thank Ad Fluit and collaborators for early provision of the whole genome sequence of an ST398 isolate. This study was supported by the PILGRIM FP7 Grant from the EU.

\section{Author Details}

Centre for Infection, Department of Cellular and Molecular Medicine, St George's, University of London, Cranmer Terrace, London SW17 ORE, UK

Received: 20 January 2010 Accepted: 15 June 2010

Published: 15 June 2010

\section{References}

1. Kluytmans J, van Belkum A, Verbrugh H: Nasal carriage of Staphylococcus aureus: epidemiology, underlying mechanisms, and associated risks. Clin Microbio/ Rev 1997, 10:505-20.

2. Gould IM: The clinical significance of methicillin-resistant Staphylococcus aureus. J Hosp Infect 2005, 61:277-82.

3. Baptiste KE, Williams K, Willams NJ, Wattret A, Clegg PD, Dawson S, Corkill JE, O'Neill T, Hart CA: Methicillin-resistant staphylococci in companion animals. Emerg Infect Dis 2005, 11:1942-4.

4. Loeffler A, Boag AK, Sung J, Lindsay JA, Guardabassi L, Dalsgaard A, Smith $H$, Stevens KB, Lloyd DH: Prevalence of methicillin-resistant Staphylococcus aureus among staff and pets in a small animal referral hospital in the UK. J Antimicrob Chemother 2005, 56:692-7.

5. Weese JS, Rousseau J, Traub-Dargatz JL, Willey BM, McGeer AJ, Low DE: Community-associated methicillin-resistant Staphylococcus aureus in horses and humans who work with horses. J Am Vet Med Assoc 2005, 226:580-3.

6. Huijsdens XW, van Dijke BJ, Spalburg E, van Santen-Verheuvel MG, Heck ME, Pluister GN, Voss A, Wannet WJ, de Neeling AJ: Community-acquired MRSA and pig-farming. Ann Glin Microbiol Antimicrob 2006, 5:26.

7. van de Giessen AW, van Santen-Verheuvel MG, Hengeveld PD, Bosch T, Broens EM, Reusken CB: Occurrence of methicillin-resistant Staphylococcus aureus in rats living on pig farms. Prev Vet Med 2009, 91:270-3.

8. Foster TJ, Höök M: Surface protein adhesins of Staphylococcus aureus. Trends Microbiol 1998, 6:484-8.

9. Clarke SR, Foster SJ: Surface adhesins of Staphylococcus aureus. Adv Microb Physiol 2006, 51:187-224.

10. Prat C, Bestebroer J, de Haas CJ, van Strijp JA, van Kessel KP: A new staphylococcal anti-inflammatory protein that antagonizes the formyl peptide receptor-like 1. J Immuno/ 2006, 177:8017-26.

11. Jongerius I, Köhl J, Pandey MK, Ruyken M, van Kessel KP, van Strijp JA, Rooijakkers SH: Staphylococcal complement evasion by various convertase blocking molecules. J Exp Med 2007, 204:2461-71.

12. Burman JD, Leung $E$, Atkins KL, O'Seaghdha MN, Lango L, Bernadó $P$, Bagby S, Svergun DI, Foster TJ, Isenman DE, van den Elsen JM: Interaction of human complement with Sbi, a staphylococcal immunoglobulinbinding protein: indications of a novel mechanism of complement evasion by Staphylococcus aureus. J Biol Chem 2008, 283:17579-93.

13. Sung JM, Lloyd DH, Lindsay JA: Staphylococcus aureus host specificity: comparative genomics of human versus animal isolates by multi-strain microarray. Microbiology 2008, 154:1949-59.

14. Sibbald MJ, Ziebandt AK, Engelmann S, Hecker M, de Jong A, Harmsen HJ, Raangs GC, Stokroos I, Arends JP, Dubois JY, van Dijl JM: Mapping the pathways to Staphylococcal pathogenesis by comparative secretomics. Microbiol Mol Biol Rev 2006, 3:755-88.

15. Feil EJ, Cooper JE, Grundmann H, Robinson DA, Enright MC, Berendt T, Peacock SJ, Smith JM, Murphy M, Spratt BG, Moore CE, Day NP: How clonal is Staphylococcus aureus? J Bacteriol 2003, 185:3307-16. 
16. Robinson DA, Enright MC: Evolutionary models of the emergence of methicillin-resistant Staphylococcus aureus. Antimicrob Agents Chemother 2003, 47:3926-34

17. Robinson DA, Enright MC: Evolution of Staphylococcus aureus by large chromosomal replacements. J Bacteriol 2004, 186:1060-4.

18. Tristan A, Bes M, Meugnier H, Lina G, Bozdogan B, Courvalin P, Reverdy ME, Enright MC, Vandenesch F, Etienne J: Global distribution of PantonValentine leukocidin--positive methicillin-resistant Staphylococcus aureus, 2006. Emerg Infect Dis 2007, 13:594-600.

19. Witte W, Strommenger B, Stanek C, Cuny C: Methicillin-resistant Staphylococcus aureus ST398 in humans and animals, Central Europe. Emerg Infect Dis 2:255-8.

20. Lowder BV, Guinane CM, Ben Zakour NL, Weinert LA, Conway-Morris A Cartwright RA, Simpson AJ, Rambaut A, Nübel U, Fitzgerald JR: Recent human-to poultry host jump, adaptation, and pandemic spread of Staphylococcus aureus. Proc Natl Acad Sci USA 2009, 106:19545-50.

21. Cockfield JD, Pathak S, Edgeworth JD, Lindsay JA: Rapid determination of hospital-acquired meticillin-resistant Staphylococcus aureus lineages. J Med Microbiol 2007, 56:614-9.

22. Mendes RE, Sader HS, Deshpande LM, Diep BA, Chambers HF, Jones RN: Characterization of Baseline Methicillin-Resistant Staphylococcus aureus Isolates Recovered from Phase IV Clinical Trial for Linezolid. J Clin Microbiol 2010, 48:568-574.

23. Roche FM, Massey R, Peacock SJ, Day NP, Visai L, Speziale P, Lam A, Pallen M, Foster TJ: Characterization of novel LPXTG-containing proteins of Staphylococcus aureus identified from genome sequences. Microbiology 2003, 149:643-54

24. Loughman A, Sweeney T, Keane FM, Pietrocola G, Speziale P, Foster TJ: Sequence diversity in the $A$ domain of Staphylococcus aureus fibronectin binding protein A. BMC Microbio/ 2008, 8:74.

25. Witney AA, Marsden GL, Holden MT, Stabler RA, Husain SE, Vass JK Butcher PD, Hinds J, Lindsay JA: Design, validation, and application of a seven-strain Staphylococcus aureus PCR product microarray for comparative genomics. Appl Environ Microbiol 2005, 71:7504-14.

26. Kuklin NA, Clark DJ, Secore S, Cook J, Cope LD, McNeely T, Noble L, Brown MJ, Zorman JK, Wang XM, Pancari G, Fan H, Isett K, Burgess B, Bryan J, Brownlow M, George H, Meinz M, Liddell ME, Kelly R, Schultz L, Montgomery D, Onishi J, Losada M, Martin M, Ebert T, Tan CY, Schofield TL, Nagy E, Meineke A, Joyce JG, Kurtz MB, Caulfield MJ, et al:: A novel Staphylococcus aureus vaccine: iron surface determinant $B$ induces rapid antibody responses in rhesus macaques and specific increased survival in a murine $\mathrm{S}$. aureus sepsis model. Infect Immun 2006, 74:2215-23.

27. Stranger-Jones $Y K$, Bae T, Schneewind O: Vaccine assembly from surface proteins of Staphylococcus aureus. Proc Natl Acad Sci USA 2006, 103:16942-7.

28. Arrecubieta C, Matsunaga I, Asai T, Naka Y, Deng MC, Lowy FD: Vaccination with clumping factor $A$ and fibronectin binding protein $A$ to prevent Staphylococcus aureus infection of an aortic patch in mice. $J$ Infect Dis 2008, 198:571-5.

29. Josefsson E, Tarkowski A: Staphylococcus aureus-induced inflammation and bone destruction in experimental models of septic arthritis. $J$ Periodontal Res 1999, 34:387-92.

30. Cheng AG, Kim HK, Burts ML, Krausz T, Schneewind O, Missiakas DM: Genetic requirements for Staphylococcus aureus abscess formation and persistence in host tissues. FASEB J 2009, 23:3393-404.

31. Fattom Al, Sarwar J, Ortiz A, Naso R: A Staphylococcus aureus capsular polysaccharide (CP) vaccine and $\mathrm{CP}$-specific antibodies protect mice against bacterial challenge. Infect Immun 1996, 64:1659-65.

32. Bubeck Wardenburg J, Schneewind O: Vaccine protection against Staphylococcus aureus pneumonia. J Exp Med 2008, 205:287-94.

33. Lindsay JA: Prospects for a MRSA vaccine. Future Microbiol 2007, 2:1-3.

34. Creech CB, Johnson BG, Alsentzer AR, Hohenboken M, Edwards KM, Talbot TR: Vaccination as infection control: a pilot study to determine the impact of Staphylococcus aureus vaccination on nasal carriage. Vaccine 2009, 28:256-60.

35. Capparelli EV, Bloom BT, Kueser TJ, Oelberg DG, Bifano EM, White RD, Schelonka RL, Pearlman SA, Patti J, Hetherington SV: Multicenter study to determine antibody concentrations and assess the safety of administration of INH-A21, a donor-selected human Staphylococcal immune globulin, in low birth-weight infants. Antimicrob Agents Chemother 2005, 49:4121-7.
36. Denis M, Wedlock DN, Lacy-Hulbert SJ, Hillerton JE, Buddle BM: Vaccines against bovine mastitis in the New Zealand context: what is the best way forward? NZVet J 2009, 57:132-40.

37. Nouwen J, Boelens $\mathrm{H}$, van Belkum A, Verbrugh $\mathrm{H}$ : Human factor in Staphylococcus aureus nasal carriage. Infect Immun 2004, 72:6685-8.

38. Mazmanian SK, Liu G, Ton-That H, Schneewind O: Staphylococcus aureus sortase, an enzyme that anchors surface proteins to the cell wall. Science 1999, 285:760-3.

39. van Wamel WJ, Rooijakkers SH, Ruyken M, van Kessel KP, van Strijp JA: The innate immune modulators staphylococcal complement inhibitor and chemotaxis inhibitory protein of Staphylococcus aureus are located on beta-hemolysin converting bacteriophages. J Bacterio/ 2006, 188:1310-5.

40. Stegger M, Lindsay JA, Sørum M, Gould KA, Skov R: Genetic diversity in CC398 methicillin-resistant Staphylococcus aureus isolates of different geographical origin. Clin Microbiol Infect 2009 in press.

41. Holden MT, Lindsay JA, Corton C, Quail MA, Cockfield JD, Pathak S, Batra R, Parkhill J, Bentley SD, Edgeworth JD: Genome sequence of a recently emerged highly-transmissible, multi-antibiotic and antiseptic resistant, variant of methicillin-resistant Staphylococcus aureus (MRSA) sequence-type 239 (TW). J Bacteriol 2010, 192:888-92.

42. Thompson JD, Higgins DG, Gibson TJ: CLUSTAL W: improving the sensitivity of progressive multiple sequence alignment through sequence weighting, position-specific gap penalties and weight matrix choice. Nucleic Acids Res 1994, 22:4673-80.

43. Hall TA: BioEdit: a user-friendly biological sequence alignment editor and analysis program for Windows 95/98/NT. Nucleic Acids Symp Ser 1999, 41:95-98.

44. Emanuelsson O, Brunak S, von Heijne G, Nielsen $\mathrm{H}$ : Locating proteins in the cell using TargetP, SignalP and related tools. Nat Protoc 2007, 2:953-71.

45. Edgeworth JD, Yadegarfar G, Pathak S, Batra R, Cockfield JD, Wyncoll D, Beale R, Lindsay JA: An outbreak in an intensive care unit of a strain of methicillin resistant Staphylococcus aureus sequence type 239 associated with an increased rate of vascular access device-related bacteremia. Clin Infect Dis 2007, 44:493-501.

46. Tang CT, Nguyen DT, Ngo TH, Nguyen TM, Le VT, To SD, Lindsay J, Nguyen TD, Bach VC, Le QT, Le TH, Le DL, Campbell J, Nguyen TK, Nguyen VV, Cockfield J, Le TG, Phan VN, Le HS, Huynh TS, Le VP, Counahan M, BentsiEnchill A, Brown R, Simmerman J, Nguyen TC, Tran TH, Farrar J, Schultsz C, et al:: An outbreak of severe infections with communityacquired MRSA carrying the Panton-Valentine leukocidin following vaccination. PLOS ONE 2007, 2:e822.

47. Vautor E, Cockfield J, Le Marechal C, Le Loir Y, Chevalier M, Robinson DA, Thiery R, Lindsay J: Difference in virulence between Staphylococcus aureus isolates causing gangrenous mastitis versus subclinical mastitis in a dairy sheep flock. Vet Res 2009, 40:56.

48. Holden MT, Feil EJ, Lindsay JA, Peacock SJ, Day NP, Enright MC, Foster TJ, Moore CE, Hurst L, Atkin R, Barron A, Bason N, Bentley SD, Chillingworth C, Chillingworth T, Churcher C, Clark L, Corton C, Cronin A, Doggett J, Dowd L, Feltwell T, Hance Z, Harris B, Hauser H, Holroyd S, Jagels K, James KD, Lennard N, Line A, Mayes R, et al:: Complete genomes of two clinical Staphylococcus aureus strains: evidence for the rapid evolution of virulence and drug resistance. Proc Natl Acad Sci USA 2004, 101:9786-91.

49. Baba T, Takeuchi F, Kuroda M, Yuzawa H, Aoki K, Oguchi A, Nagai Y, I wama N, Asano K, Naimi T, Kuroda H, Cui L, Yamamoto K, Hiramatsu K: Genome and virulence determinants of high virulence community-acquired MRSA. Lancet 2002, 359:1819-27.

50. Rolain JM, François P, Hernandez D, Bittar F, Richet H, Fournous G, Mattenberger Y, Bosdure E, Stremler N, Dubus JC, Sarles J, ReynaudGaubert M, Boniface S, Schrenzel J, Raoult D: Genomic analysis of an emerging multiresistant Staphylococcus aureus strain rapidly spreading in cystic fibrosis patients revealed the presence of an antibiotic inducible bacteriophage. Biol Direct 2009, 4:1.

51. Neoh HM, Cui L, Yuzawa H, Takeuchi F, Matsuo M, Hiramatsu K: Mutated response regulator graR is responsible for phenotypic conversion of Staphylococcus aureus from heterogeneous vancomycin-intermediate resistance to vancomycin-intermediate resistance. Antimicrob Agents Chemother 2008, 52:45-53.

52. Kuroda M, Ohta T, Uchiyama I, Baba T, Yuzawa H, Kobayashi I, Cui L, Oguchi A, Aoki K, Nagai Y, Lian J, Ito T, Kanamori M, Matsumaru H, Maruyama A, Murakami H, Hosoyama A, Mizutani-Ui Y, Takahashi NK, 
Sawano T, Inoue R, Kaito C, Sekimizu K, Hirakawa H, Kuhara S, Goto S, Yabuzaki J, Kanehisa M, Yamashita A, Oshima K, Furuya K, et al:: Whole genome sequencing of meticillin-resistant Staphylococcus aureus. Lancet 2001, 357:1225-40

53. Mwangi MM, Wu SW, Zhou Y, Sieradzki K, de Lencastre H, Richardson $P$, Bruce D, Rubin E, Myers E, Siggia ED, Tomasz A: Tracking the in vivo evolution of multidrug resistance in Staphylococcus aureus by wholegenome sequencing. Proc Natl Acad Sci USA 2007, 104:9451-6.

54. Gillaspy AF, Worrell V, Orvis J, Roe BA, Dyer DW, landolo JJ: The Staphylococcus aureus NCTC 8325 Genome. In Gram-positive pathogens 2nd edition. Edited by: Fischetti VA, Novick RP, Ferretti JJ, Portnoy DA, Rood JI. ASM Press, Washington D.C; 2006:381-412.

55. Baba T, Bae T, Schneewind O, Takeuchi F, Hiramatsu K: Genome sequence of Staphylococcus aureus strain Newman and comparative analysis of staphylococcal genomes: polymorphism and evolution of two major pathogenicity islands. J Bacterio/ 2008, 190:300-10.

56. Diep BA, Gill SR, Chang RF, Phan TH, Chen JH, Davidson MG, Lin F, Lin J, Carleton HA, Mongodin EF, Sensabaugh GF, Perdreau-Remington F: Complete genome sequence of USA300, an epidemic clone of community-acquired meticillin-resistant Staphylococcus aureus. Lancet 2006, 367:731-9.

57. Highlander SK, Hultén KG, Qin X, Jiang H, Yerrapragada S, Mason EO Jr, Shang Y, Williams TM, Fortunov RM, Liu Y, Igboeli O, Petrosino J, Tirumalai M, Uzman A, Fox GE, Cardenas AM, Muzny DM, Hemphill L, Ding Y, Dugan S, Blyth PR, Buhay CJ, Dinh HH, Hawes AC, Holder M, Kovar CL, Lee SL, Liu W, Nazareth LV, Wang Q, Zhou J, et al:: Subtle genetic changes enhance virulence of methicillin resistant and sensitive Staphylococcus aureus. BMC Microbiol 2007, 7:99.

58. Gill SR, Fouts DE, Archer GL, Mongodin EF, Deboy RT, Ravel J, Paulsen IT, Kolonay JF, Brinkac L, Beanan M, Dodson RJ, Daugherty SC, Madupu R, Angiuoli SV, Durkin AS, Haft DH, Vamathevan J, Khouri H, Utterback T, Lee C, Dimitrov G, Jiang L, Qin H, Weidman J, Tran K, Kang K, Hance IR, Nelson $K E$, Fraser CM: Insights on evolution of virulence and resistance from the complete genome analysis of an early methicillin-resistant Staphylococcus aureus strain and a biofilm-producing methicillinresistant Staphylococcus epidermidis strain. J Bacteriol 2005, 187:2426-38.

59. Herron-Olson L, Fitzgerald JR, Musser JM, Kapur V: Molecular correlates of host specialization in Staphylococcus aureus. PLOS ONE 2007, 2:e1120.

60. Heilmann C, Hartleib J, Hussain MS, Peters G: The multifunctional Staphylococcus aureus autolysin aaa mediates adherence to immobilized fibrinogen and fibronectin. Infect Immun 2005, 73:4793-802.

61. Ganesh VK, Rivera JJ, Smeds E, Ko YP, Bowden MG, Wann ER, Gurusiddappa S, Fitzgerald JR, Höök M: A structural model of the Staphylococcus aureus CIfA fibrinogen interaction opens new avenues for the design of anti-staphylococcal therapeutics. PLoS Pathog 2008, 4:e1000226

62. McDevitt D, Nanavaty T, House-Pompeo K, Bell E, Turner N, McIntire L, Foster T, Höök M: Characterization of the interaction between the Staphylococcus aureus clumping factor (ClfA) and fibrinogen. Eur J Biochem 1997, 247:416-24.

63. Josefsson E, Higgins J, Foster TJ, Tarkowski A: Fibrinogen binding sites P336 and Y338 of clumping factor A are crucial for Staphylococcus aureus virulence. PLoS One 2008, 3:e2206

64. Walsh EJ, Miajlovic H, Gorkun OV, Foster TJ: Identification of the Staphylococcus aureus MSCRAMM clumping factor B (ClfB) binding site in the alphaC-domain of human fibrinogen. Microbiology 2008, 154:550-8.

65. Ní Eidhin D, Perkins $S$, Francois $P$, Vaudaux $P$, Höök $M$, Foster TJ: Clumping factor B (ClfB), a new surface-located fibrinogen-binding adhesin of Staphylococcus aureus. Mol Microbiol 1998, 30:245-57

66. Patti JM, Jonsson H, Guss B, Switalski LM, Wiberg K, Lindberg M, Höök M: Molecular characterization and expression of a gene encoding a Staphylococcus aureus collagen adhesin. J Biol Chem 1992, 267:4766-72.

67. Symersky J, Patti JM, Carson M, House-Pompeo K, Teale M, Moore D, Jin L, Schneider A, DeLucas LJ, Höök M, Narayana SV: Structure of the collagenbinding domain from a Staphylococcus aureus adhesin. Nat Struct Biol 1997, 4:833-8.
68. Zong Y, Xu Y, Liang X, Keene DR, Höök A, Gurusiddappa S, Höök M, Narayana SV: A 'Collagen Hug' model for Staphylococcus aureus CNA binding to collagen. EMBO J 2005, 24:4224-36

69. Watanabe S, Ito T, Takeuchi F, Endo M, Okuno E, Hiramatsu K: Structural comparison of ten serotypes of staphylocoagulases in Staphylococcus aureus. J Bacterio/ 2005, 187:3698-707

70. Watanabe S, Ito T, Sasaki T, Li S, Uchiyama I, Kishii K, Kikuchi K, Skov RL, Hiramatsu K: Genetic diversity of staphylocoagulase genes (coa): insight into the evolution of variable chromosomal virulence factors in Staphylococcus aureus. PLoS One 2009, 4:

71. Hussain M, von Eiff C, Sinha B, Joost I, Herrmann M, Peters G, Becker K: eap Gene as novel target for specific identification of Staphylococcus aureus. J Glin Microbio/ 2008, 46:470-6.

72. Hussain M, Haggar A, Peters G, Chhatwal GS, Herrmann M, Flock Jl, Sinha $B$ : More than one tandem repeat domain of the extracellular adherence protein of Staphylococcus aureus is required for aggregation, adherence, and host cell invasion but not for leukocyte activation. Infect Immun 2008, 76:5615-23.

73. Scriba TJ, Sierro S, Brown EL, Phillips RE, Sewell AK, Massey RC: The Staphyloccous aureus Eap protein activates expression of proinflammatory cytokines. Infect Immun 2008, 76:2164-8.

74. Clarke SR, Harris LG, Richards RG, Foster SJ: Analysis of Ebh, a 1.1megadalton cell wall-associated fibronectin-binding protein of Staphylococcus aureus. Infect Immun 2002, 70:6680-7.

75. Kuroda M, Tanaka Y, Aoki R, Shu D, Tsumoto K, Ohta T: Staphylococcus aureus giant protein Ebh is involved in tolerance to transient hyperosmotic pressure. Biochem Biophys Res Commun 2008, 374:237-41.

76. Sakamoto S, Tanaka Y, Tanaka I, Takei T, Yu J, Kuroda M, Yao M, Ohta T, Tsumoto K: Electron microscopy and computational studies of Ebh, a giant cell wall-associated protein from Staphylococcus aureus. Biochem Biophys Res Commun 2008, 376:261-6.

77. Tanaka Y, Sakamoto S, Kuroda M, Goda S, Gao YG, Tsumoto K, Hiragi Y, Yao M, Watanabe N, Ohta T, Tanaka I: A helical string of alternately connected three- helix bundles for the cell wall-associated adhesion protein Ebh from Staphylococcus aureus. Structure 2008, 16:488-96.

78. Park PW, Broekelmann TJ, Mecham BR, Mecham RP: Characterization of the elastin binding domain in the cell-surface 25-kDa elastin-binding protein of staphylococcus aureus (EbpS). J Biol Chem 1999, 274:2845-50.

79. Downer R, Roche F, Park PW, Mecham RP, Foster TJ: The elastin-binding protein of Staphylococcus aureus (EbpS) is expressed at the cell surface as an integral membrane protein and not as a cell wallassociated protein. J Biol Chem 2002, 277:243-50.

80. Nakakido M, Tanaka Y, Tsumoto K: The N-terminal domain of elastinbinding protein of Staphylococcus aureus changes its secondary structure in a membrane-mimetic environment. J Biochem 2007, 142:131-4.

81. Bodén MK, Flock Jl: Cloning and characterization of a gene for a $19 \mathrm{kDa}$ fibrinogen-binding protein from Staphylococcus aureus. Mol Microbiol 1994, 12:599-606.

82. Palma M, Wade D, Flock M, Flock Jl: Multiple binding sites in the interaction between an extracellular fibrinogen-binding protein from Staphylococcus aureus and fibrinogen. J Biol Chem 1998, 273:13177-81.

83. Lee LY, Liang $X$, Höök M, Brown EL: Identification and characterization of the $\mathrm{C} 3$ binding domain of the Staphylococcus aureus extracellular fibrinogen- binding protein (Efb). J Biol Chem 2004, 279:50710-6.

84. Hussain M, Becker K, von Eiff C, Schrenzel J, Peters G, Herrmann M: Identification and characterization of a novel 38.5-kilodalton cell surface protein of Staphylococcus aureus with extended-spectrum binding activity for extracellular matrix and plasma proteins. J Bacterio/ 2001, 183:6778-86.

85. Burts ML, Williams WA, DeBord K, Missiakas DM: EsxA and EsxB are secreted by an ESAT-6-like system that is required for the pathogenesis of Staphylococcus aureus infections. Proc Natl Acad Sci USA 2005, 102:1169-74.

86. Burts ML, DeDent AC, Missiakas DM: EsaC substrate for the ESAT-6 secretion pathway and its role in persistent infections of Staphylococcus aureus. Mol Microbiol 2008, 69:736-46.

87. Komatsuzawa H, Choi GH, Fujiwara T, Huang Y, Ohta K, Sugai M, Suginaka $\mathrm{H}$ : Identification of a fmtA-like gene that has similarity to other PBPs and beta lactamases in Staphylococcus aureus. FEMS Microbiol Lett 2000, 188:35-9. 
88. Wann ER, Gurusiddappa S, Hook M: The fibronectin-binding MSCRAMM FnbpA of Staphylococcus aureus is a bifunctional protein that also binds to fibrinogen. J Biol Chem 2000, 275:13863-71.

89. Roche FM, Downer R, Keane F, Speziale P, Park PW, Foster TJ: The Nterminal $A$ domain of fibronectin-binding proteins $A$ and $B$ promotes adhesion of Staphylococcus aureus to elastin. J Biol Chem 2004, 279:38433-40.

90. Palmqvist N, Foster T, Fitzgerald JR, Josefsson E, Tarkowski A: Fibronectin binding proteins and fibrinogen-binding clumping factors play distinct roles in staphylococcal arthritis and systemic inflammation. $J$ Infect Dis 2005, 191:791.

91. Keane FM, Loughman A, Valtulina V, Brennan M, Speziale P, Foster TJ: Fibrinogen and elastin bind to the same region within the $A$ domain of fibronectin binding protein A, an MSCRAMM of Staphylococcus aureus. Mol Microbiol 2007, 63:711-23.

92. Bingham RJ, Rudiño-Piñera E, Meenan NA, Schwarz-Linek U, Turkenburg $J P$, Höök M, Garman EF, Potts JR: Crystal structures of fibronectinbinding sites from Staphylococcus aureus FnBPA in complex with fibronectin domains. Proc Natl Acad Sci USA 2008, 105:12254-8.

93. Heying R, van de Gevel J, Que YA, Piroth L, Moreillon P, Beekhuizen H: Contribution of (sub)domains of Staphylococcus aureus fibronectinbinding protein to the proinflammatory and procoagulant response of human vascular endothelial cells. Thromb Haemost 2009, 101:495-504.

94. Mackey-Lawrence NM, Potter DE, Cerca N, Jefferson KK: Staphylococcus aureus immunodominant surface antigen $B$ is a cell-surface associated nucleic acid binding protein. BMC Microbiol 2009, 9:61.

95. Clarke SR, Wiltshire MD, Foster SJ: IsdA of Staphylococcus aureus is a broad spectrum, iron-regulated adhesin. Mol Microbiol 2004, 51:1509-19.

96. Clarke SR, Andre G, Walsh EJ, Dufrêne YF, Foster TJ, Foster SJ: Ironregulated surface determinant protein $A$ mediates adhesion of Staphylococcus aureus to human corneocyte envelope proteins. Infect Immun 2009, 77:2408-16.

97. Mazmanian SK, Skaar EP, Gaspar AH, Humayun M, Gornicki P, Jelenska J, Joachmiak A, Missiakas DM, Schneewind O: Passage of heme-iron across the envelope of Staphylococcus aureus. Science 2003, 299:906-9.

98. Visai L, Yanagisawa N, Josefsson E, Tarkowski A, Pezzali I, Rooijakkers SH, Foster TJ, Speziale P: Immune evasion by Staphylococcus aureus conferred by iron-regulated surface determinant protein Is $\mathrm{dH}$. Microbiology 2009, 155:667-79.

99. Schroeder K, Jularic M, Horsburgh SM, Hirschhausen N, Neumann C, Bertling A, Schulte A, Foster S, Kehrel BE, Peters G, Heilmann C: Molecular characterization of a novel Staphylococcus aureus surface protein (SasC) involved in cell aggregation and biofilm accumulation. PLoS One 2009:4.

100. DeDent A, Bae T, Missiakas DM, Schneewind O: Signal peptides direct surface proteins to two distinct envelope locations of Staphylococcus aureus. EMBO J 2008, 27:2656-68

101. Corrigan RM, Rigby D, Handley P, Foster TJ: The role of Staphylococcus aureus surface protein Sas $G$ in adherence and biofilm formation. Microbiology 2007, 153:2435-46.

102. Kuroda M, Ito R, Tanaka Y, Yao M, Matoba K, Saito S, Tanaka I, Ohta T: Staphylococcus aureus surface protein SasG contributes to intercellular autoaggregation of Staphylococcus aureus. Biochem Biophys Res Commun 2008, 377:1102-6.

103. Thammavongsa V, Kern JW, Missiakas DM, Schneewind O: Staphylococcus aureus synthesizes adenosine to escape host immune responses. J Exp Med 2009, 206:2417-27.

104. Haupt K, Reuter M, van den Elsen J, Burman J, Hälbich S, Richter J, Skerka C, Zipfel PF: The Staphylococcus aureus protein Sbi acts as a complement inhibitor and forms a tripartite complex with host complement Factor H and C3b. PLoS Pathog 2008, 4:.

105. Upadhyay A, Burman JD, Clark EA, Leung E, Isenman DE, van den Elsen JM, Bagby S: Structure-function analysis of the $\mathrm{C} 3$ binding region of Staphylococcus aureus immune subversion protein Sbi. J Biol Chem 2008, 283:22113-20.

106. Josefsson E, McCrea KW, Ní Eidhin D, O'Connell D, Cox J, Höök M, Foster TJ: Three new members of the serine-aspartate repeat protein multigene family of Staphylococcus aureus. Microbiology 1998, 144:3387-95.

107. Corrigan RM, Miajlovic H, Foster TJ: Surface proteins that promote adherence of Staphylococcus aureus to human desquamated nasal epithelial cells. BMC Microbiol 2009, 9:22.
108. Josefsson E, O'Connell D, Foster TJ, Durussel I, Cox JA: The binding of calcium to the B-repeat segment of SdrD, a cell surface protein of Staphylococcus aureus. J Biol Chem 1998, 273:31145-52.

109. Zhang L, Xiang H, Gao J, Hu J, Miao S, Wang L, Deng X, Li S: Purification, characterization, and crystallization of the adhesive domain of SdrD from Staphylococcus aureus. Protein Expr Purif 2009, 69:204-8.

110. Uhlén M, Guss B, Nilsson B, Gatenbeck S, Philipson L, Lindberg M: Complete sequence of the staphylococcal gene encoding protein $A$. A gene evolved through multiple duplications. J Biol Chem 1984, 259:1695-702

111. Hartleib J, Köhler N, Dickinson RB, Chhatwal GS, Sixma JJ, Hartford OM, Foster TJ, Peters G, Kehrel BE, Herrmann M: Protein A is the von Willebrand factor binding protein on Staphylococcus aureus. Blood 2000, 96:2149-56

112. Gómez MI, Lee A, Reddy B, Muir A, Soong G, Pitt A, Cheung A, Prince A: Staphylococcus aureus protein $A$ induces airway epithelial inflammatory responses by activating TNFR1. Nat Med 2004, 10:842-8

113. Siboo IR, Chambers HF, Sullam PM: Role of SraP, a Serine-Rich Surface Protein of Staphylococcus aureus, in binding to human platelets. Infect Immun 2005, 73:2273-80.

114. Takamatsu D, Hata E, Osaki M, Aso H, Kobayashi S, Sekizaki T: Role of SraP in adherence of Staphylococcus aureus to the bovine mammary epithelia. J Vet Med Sci 2008, 70:735-8.

115. Bjerketorp J, Nilsson M, Ljungh A, Flock Jl, Jacobsson K, Frykberg L: A novel von Willebrand factor binding protein expressed by Staphylococcus aureus. Microbiology 2002, 148:2037-44.

116. O'Seaghdha M, van Schooten CJ, Kerrigan SW, Emsley J, Silverman GJ, Cox D, Lenting PJ, Foster TJ: Staphylococcus aureus protein A binding to von Willebrand factor $\mathrm{A} 1$ domain is mediated by conserved IgG binding regions. FEBS J 2006, 273:4831-41

117. Kroh HK, Panizzi P, Bock PE: Von Willebrand factor-binding protein is a hysteretic conformational activator of prothrombin. Proc Natl Acad SC USA 2009, 106:7786-91.

118. Liang OD, Flock Jl, Wadström T: Isolation and characterisation of a vitronectin-binding surface protein from Staphylococcus aureus. Biochim Biophys Acta 1995, 1250:1 10-6.

doi: 10.1186/1471-2180-10-173

Cite this article as: McCarthy and Lindsay, Genetic variation in Staphylococcus aureus surface and immune evasion genes is lineage associated: implications for vaccine design and host-pathogen interactions BMC Microbiology 2010, 10:173

\section{Submit your next manuscript to BioMed Centra and take full advantage of:}

- Convenient online submission

- Thorough peer review

- No space constraints or color figure charges

- Immediate publication on acceptance

- Inclusion in PubMed, CAS, Scopus and Google Scholar

- Research which is freely available for redistribution 